\title{
In vivo Wear Pattern of Experimental Light-cured Hybrid Composite Resins
}

\author{
Akira OKAMOTO, Kazuhito SEKIYA, Masayoshi FUKUSHIMA and Masaaki IWAKU \\ Department of Operative Dentistry and Endodontics, Niigata University School of Dentistry, \\ 5274, Gakkocho-dori 2-bancho Niigata 951, Japan
}

Received July 19, 1993/Accepted October 15, 1993

\begin{abstract}
This study evaluated the effect of various types of microfiller on the in vivo wear resistance of composite resins. Experimental light-cured composites with two different microfiller systems were prepared : (1) $56 \mathrm{wt}$ $\%$ fine quartz filler, $21 \mathrm{wt} \%$ organic filler and $3 \mathrm{wt} \%$ colloidal silica filler (Hybrid type 1), and (2) $64 \mathrm{wt} \%$ fine quartz filler and $21 \mathrm{wt} \%$ colloidal silica filler (Hybrid type 2). The resin monomer consisted of $50 \mathrm{wt}$ $\%$ Bis-GMA and $50 \mathrm{wt} \%$ TEGDMA. These materials were placed in $2 \mathrm{~mm}$ diameter cylindrical cavities located in the OCA (occlusal contact area) or the CFA (contact free area) in cast gold-silver-palladium alloy full coverage crowns, which were temporarily set in a volunteer patient's mouth. The crowns were removed at monthly intervals for SEM observation. Hybrid type 1, which contained organic fillers, showed bulk fractures in the OCA, by the second month of the experiment. However, reinforcement of the resin matrix by dispersion of microfiller provided Hybrid type 2 with superior wear resistance for up to two months.
\end{abstract}

Key words: Wear, Hybrid composite, SEM observation

\section{INTRODUCTION}

Amalgam has, until recently, been regarded as the standard material for use in direct fillings of posterior restorations. Now, however, with the ever greater demand for esthetic dentistry and, especially in Japan, the increasing awareness of the environmental damage caused by mercury, composite resins are being used on a much wider scale for Class I and Class II restorations. The most frequent clinical problem associated with the first generation of conventional composites was occlusal wear. Recent developments in filler and monomer systems of composite resins hold the promise of improving wear resistance. At this stage, however, little is known about the structural effects of composite resin on in vivo wear behavior. A prior comparative study ${ }^{1)}$ described a method using temporary metal crowns, whereby in vivo wear patterns of conventional and MFR composites were examined by SEM (scanning electron microscope). In the present study, the occlusal wear pattern of experimental light-cured hybrid composites with two different microfiller systems were examined.

\section{MATERIALS AND METHODS}

Experimental light-cured composite resins* with two different microfiller systems, Hybrid types 1 and 2, were used in this study. Hybrid type 1 consisted of $56 \mathrm{wt} \%$ fine quartz filler,

* Experimental materials, Kuraray Co., Ltd., Osaka, Japan 
$21 \mathrm{wt} \%$ organic filler and $3 \mathrm{wt} \%$ colloidal silica filler. Hybrid type 2 was formulated from $64 \mathrm{wt} \%$ fine quartz filler and $21 \mathrm{wt} \%$ colloidal silica filler (Table 1). The principal composition of the resin monomer was $50 \mathrm{wt} \%$ Bis-GMA and $50 \mathrm{wt} \%$ TEGDMA (Table 2).

In vivo wear patterns of the composite resins detailed here are similar in all respects to those reported in a previous study ${ }^{1)}$, in that, young adult volunteer-patients (24-26 years old) needing full-crown molar restorations were used for the study and the crowns came into direct contact with enamel antagonists. First, cast gold-silver-palladium alloy** full coverage crowns were formed for these molars, and three or four small cylindrical cavities $(2 \mathrm{~mm}$ in diameter $\times 1 \mathrm{~mm}$ in depth) limited to the occlusal contact area (OCA) or contact free area (CFA) were prepared, on each occlusal surface of the crowns (Fig. 1). The composite resins were then placed into the prepared cavities. After occlusal adjustments were made, to assure the proper fit, these resin fillings were polished using silicon polishing points\# and $0.06 \mu \mathrm{m}$ alumina paste ${ }^{\#}$. Before placing in the moth, the fillings were gold-ion coated ${ }^{\circledR}$, and observed at the baseline, by SEM@@. These micrographs showing the centers of the fillings

Table 1 Formulas for two experimental composite resins (wt \%)

\begin{tabular}{|c|c|c|c|}
\hline & & $\begin{array}{l}\text { Hybrid } \\
\text { type } 1\end{array}$ & $\begin{array}{c}\text { Hybrid } \\
\text { type } 2\end{array}$ \\
\hline \multicolumn{2}{|r|}{ Filler ${ }^{1)}$} & 80 & 85 \\
\hline & Fine quartz filler ${ }^{2}$ & $(56)$ & $(64)$ \\
\hline & Organic filler ${ }^{3)}$ & $(21)$ & $(-)$ \\
\hline & $\begin{array}{l}\text { Colloidal silica filler } \\
\text { treated with silane }\end{array}$ & $(3)$ & $(21)$ \\
\hline \multicolumn{2}{|r|}{ Monomer } & 20 & 15 \\
\hline \multicolumn{4}{|c|}{ 1) Coupling agent: $\gamma$-methacryloxypropyltrimethoxy silane } \\
\hline \multicolumn{4}{|c|}{ The mean particle-size is 4 micrometers in diameter. } \\
\hline \multirow[t]{2}{*}{ 3) } & \multicolumn{3}{|c|}{ Resin binder: Bis-GMA/TEGDMA (50wt\%/50wt\%) 40wt\% } \\
\hline & \multicolumn{3}{|l|}{ Colloidal silica filler $60 \mathrm{wt} \%$} \\
\hline 4) & \multicolumn{3}{|c|}{ The mean particle-size is 0.04 micrometers in diameter. } \\
\hline
\end{tabular}

Table 2 Monomer composition of experimental resins (wt \%)

\begin{tabular}{lc}
\hline Bis-GMA & 50 \\
TEGDMA & 50 \\
Camphoroquinone & 0.5 \\
Dimethylaminoethylmethacrylate & 2.0 \\
Inhibitor & small amount \\
Pigments & small amount \\
\hline
\end{tabular}

** Pallatop 12, Sankin Industry Co. Ltd., Tokyo, Japan

\# Silicone point M-2 \& M-3, Shofu Co. Ltd., Kyoto, Japan

\# Alumina polishing powder, Marumoto Industry Co. Ltd., Tokyo, Japan

@ Ion Coater IB 3, Eiko Engineering, Co. Ltd., Ibaragi, Japan

@@ S-430, Hitachi Co. Ltd., Tokyo, Japan 
were taken at magnifications of $50 \times, 200 \times, 1000 \times$ and $3000 \times$. The crowns were successively removed, after one and two months, and microstructures of the worn surfaces of each material were longitudinally compared with beseline figures. Three fillings were observed in each group.

\section{RESULTS}

The wear processes in Hybrid type 1 and 2 composites are shown in Fig. 1-4 and Fig. 5-8, respectively.

Wear-damage was greater in the OCA than in the CFA for both types of hybrid composites.

Photographs of Hybrid type 1 composite in the CFA, taken over a period of two months,
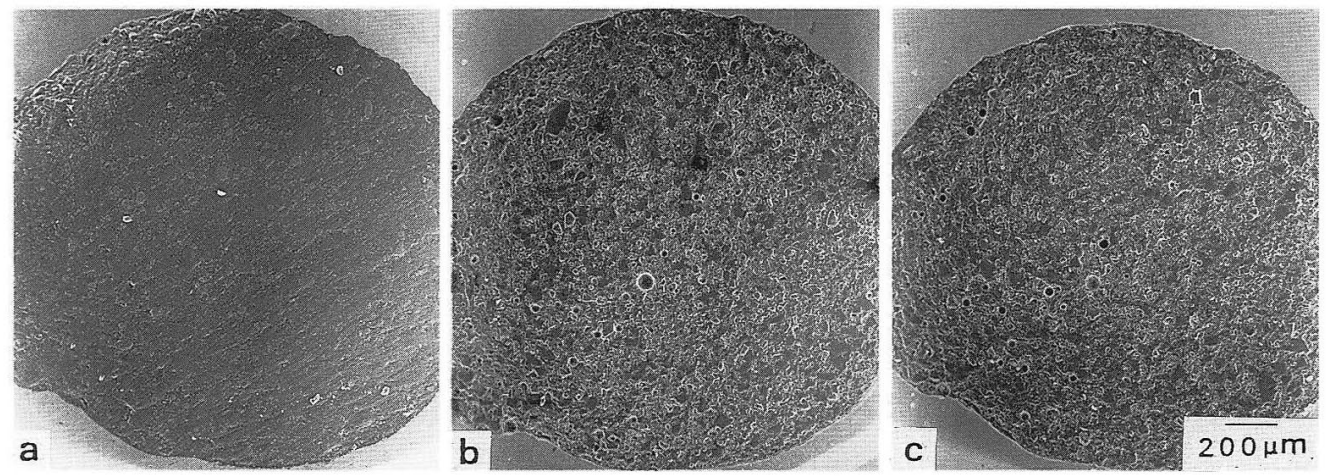

Fig. 1 Serial SEM pictures of the wear process on Hybrid type 1 composite in CFA. Original magnification $50 \times$.

(a: base-line b: 1 month $\mathrm{c}: 2$ months)
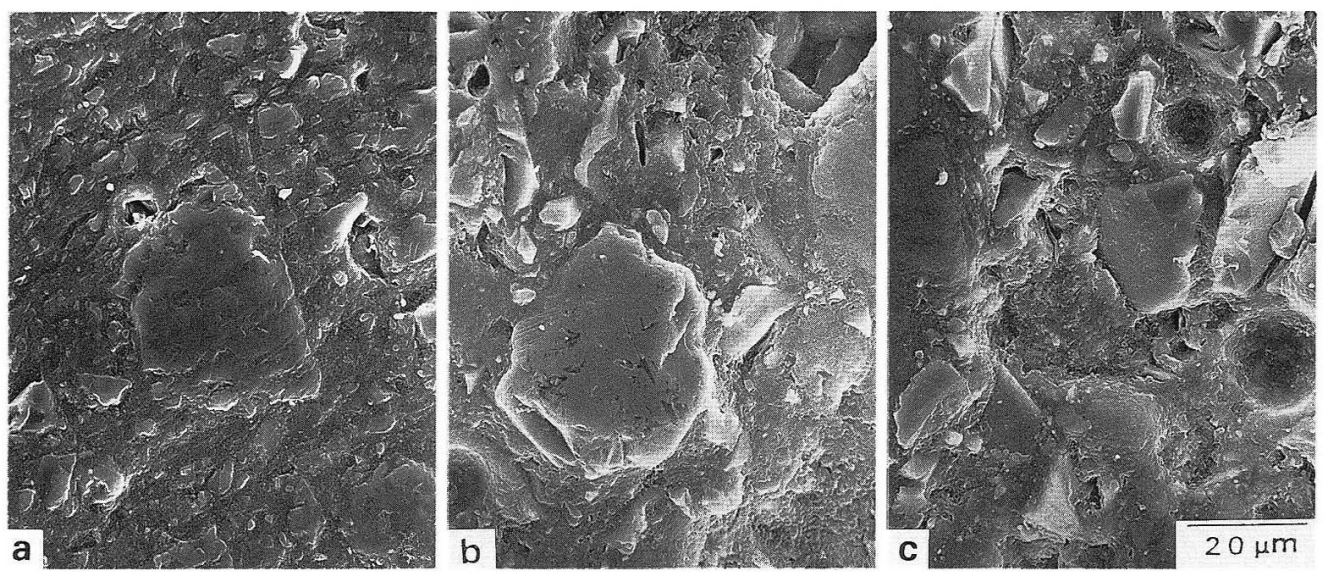

Fig. 2 Serial SEM pictures of the wear process on Hybrid type 1 composite in CFA. Original magnification $1000 \times$.

(a: base-line b: 1 month c: 2 months) 
showed that surface roughness increased slightly, with filler-contours becoming distinct (Fig. 1). The higher magnification of the CFA (Fig. 2) showed the preferred abrasion of the matrix resin and dislocation of quartz filler particles, after two months. However, the organic fillers showed higher resistance to wear than the quartz fillers. In the OCA, the resin surface showed bulk fracture followed by loss of material (Fig. 3). At a higher magnification, microcracks, possibly attributable to fatigue, were observed along the interface between the organic fillers, which were subsequently lost, resulting in marked bulk fracturing (Fig. 4).

Sequential low-level magnifications of Hybrid type 2 in the CFA (Fig. 5) show that the surface texture underwent little change, at two months. Even under high magnification, there appeared to be little abrasion of resin matrix, so that, after two months, the fillers were
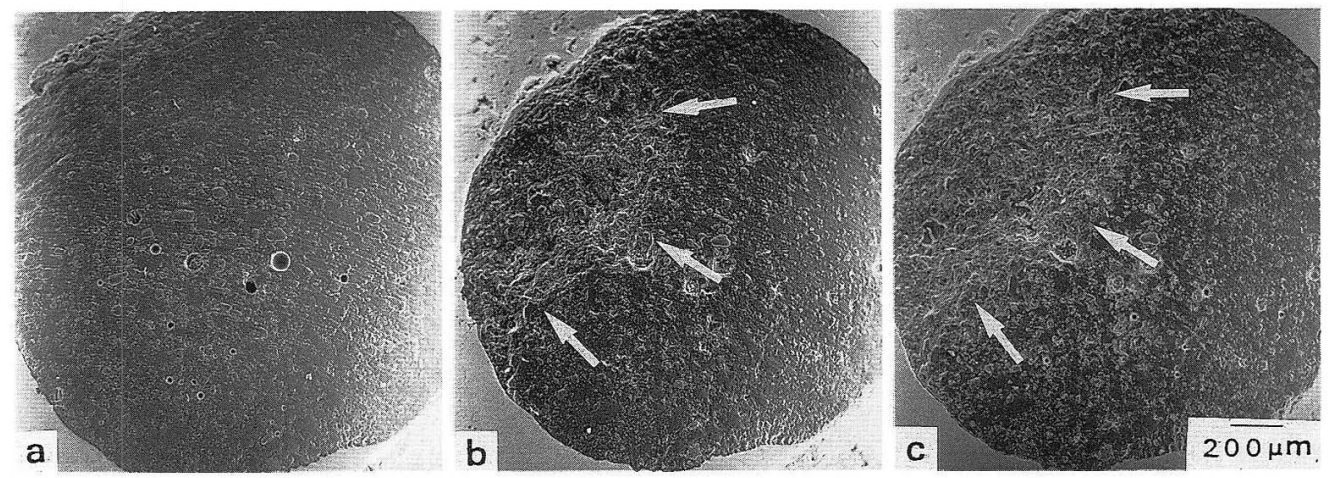

Fig. 3 Serial SEM pictures of the wear process on Hybrid type 1 composite in OCA. Original magnification $50 \times$.

(a: base-line $\mathrm{b}: 1$ month $\mathrm{c}: 2$ months)

White arrows indicate wear facets.


Fig. 4 Serial SEM pictures of the wear process on Hybrid type 1 composite in OCA. Original magnification $1000 \times$.

(a: base-line b: 1 month $\mathrm{c}: 2$ months) 
still tightly supported in the resin matrix (Fig.6). However, a distinct wear facet was observed in the OCA (Fig. 7), the surface of which was relatively smooth. Under higher magnification, the surface of the OCA appeared ground away and some fillers were chipped, under the high occlusal stress (Fig. 8).

From the previous study ${ }^{1)}$ and these observations in the OCA and the CFA, Hybrid type2 showed the greatest wear resistance by the second month. The dispersion of colloidal silica among larger filler particles was effective in enhancing the wear resistance of the resin matrix itself.
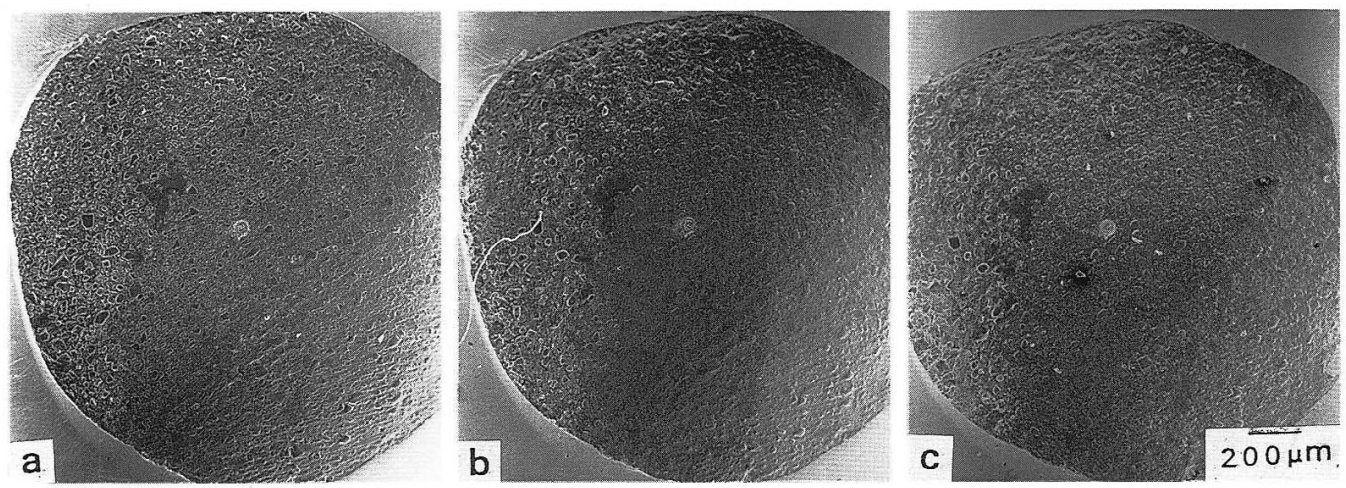

Fig. 5 Serial SEM pictures of the wear process on Hybrid type 2 composite in CFA. Original magnification $50 \times$.

(a: base-line b: 1 month c : 2 months)
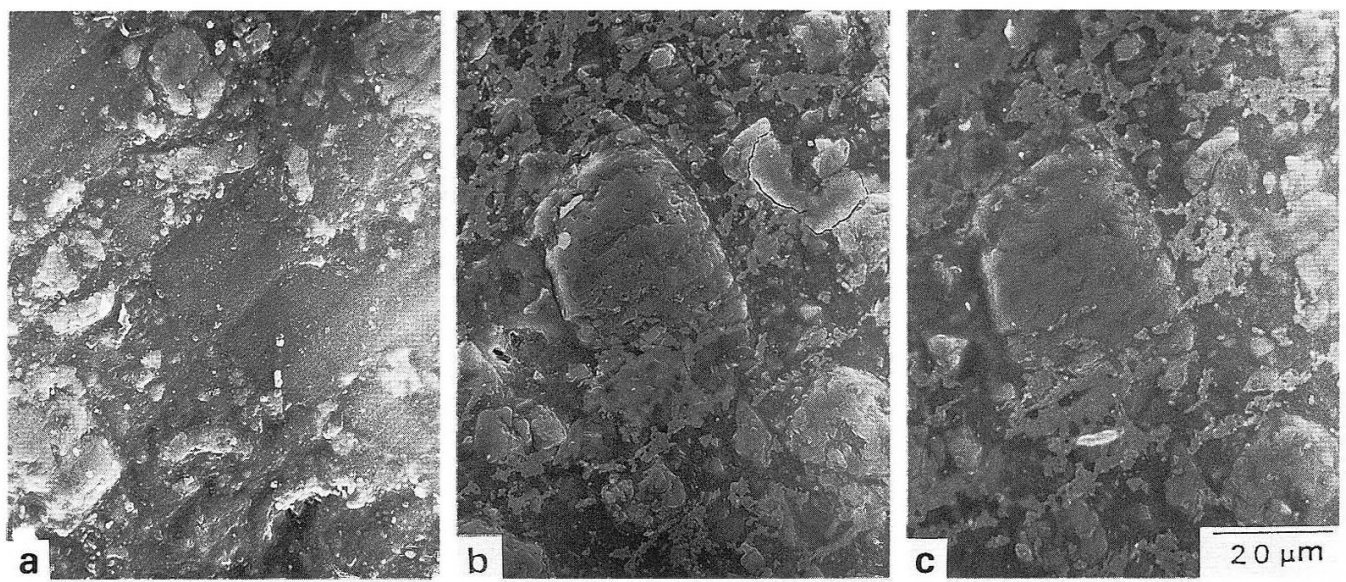

Fig. 6 Serial SEM pictures of the wear process on Hybrid type 2 composite in CFA. Original magnification $1000 \times$.

(a: base-line b: 1 month c: 2 months) 


\section{DISCUSSION}

A number of classification systems have been proposed for composite resins ${ }^{2-9)}$. Recently developed "Hybrid composites" have become popular for use as stress bearing anterior or posterior composite restorative materials. The hybrid composite can be generally described as a composite that contains two different sizes of filler, ground fillers $(1-30 \mu \mathrm{m})$ and microfillers $(0.04 \mu \mathrm{m})$. The incorporation of submicron filler in composites can be traced to such conventional composites as Adaptic and Concise, where it was used to improve viscosity and / or handling characteristics ${ }^{2)}$. In the modern hybrid composites, these microfillers were used to augment various physical and mechanical properties ${ }^{10}$. The results of this study
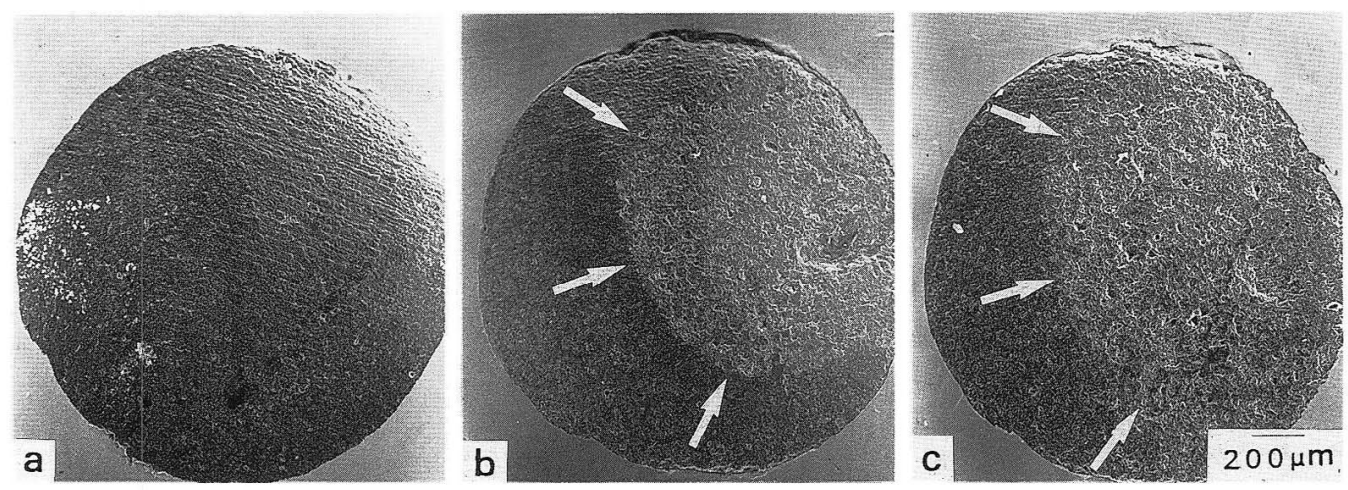

Fig. 7 Serial SEM pictures of the wear process on Hybrid type 2 composite in OCA.

Original magnification $50 \times$.

(a: base-line b:1 month c: 2 months)

White arrows indicate the wear facets.
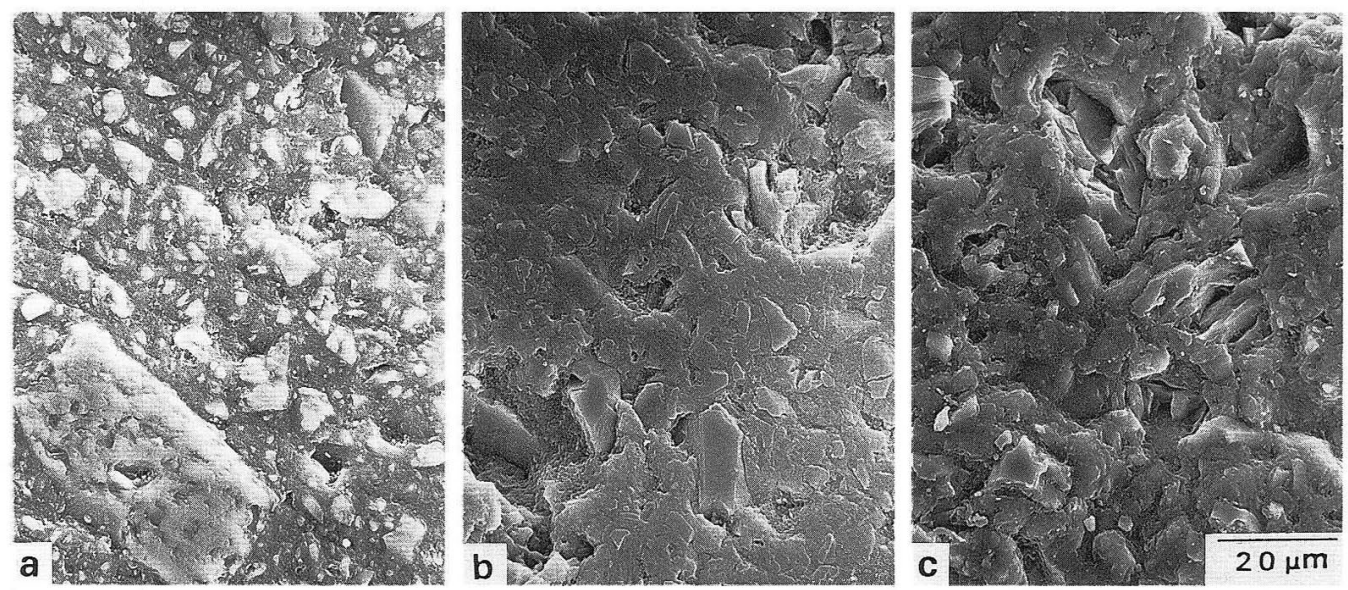

Fig. 8 Serial SEM pictures of the wear process on Hybrid type 2 composite in OCA. Original magnification $1000 \times$.

(a: base-line b: 1 month $\mathrm{c}: 2$ months) 
revealed that the wear pattern of composite resins was effectively changed by the use of additional microfillers.

Wear patterns in each of four experimental composite resins were distinct, as reported in a previous study ${ }^{1)}$ and confirmed in this study. The wear facet in the OCA was divided into two groups. MFR and Hybrid type 1 showed bulk fracturing followed by loss of material.The degree of catastrophic damage was more severe in the former, than in the latter. The localized wear in the central holding areas may be caused by the microcracking and debonding of the prepolymerized particles from the resin matrix ${ }^{4,12)}$. These types may be not suited to occlusal posterior restorations. In the CFA, the organic fillers showed higher resistance to abrasive wear from food bolus. MFR has become the resin of choice for esthetic restoration of anterior teeth, particularly in non-stress bearing situations ${ }^{9)}$. The mechanical properties of hybrid type 1 were higher than those of $\mathrm{MFR}^{11}$. In this study, hybrid type 1 contained the same type of macrofillers as used conventionally. When smaller and softer glass macrofillers are used in hybrid type 2 cases, the smooth surface necessary for esthetic restorations in obtainable, making this type useful for anterior restorations, including the stress-bearing Class IV and veneer restorations.

Hybrid type 2 showed a distinct wear facet in the OCA similar to that of conventional types. However, the surface roughness of the wear facet in hybrid type 2 was relatively smooth, when compared with that of the conventional variety. Furthermore, in the CFA, the resin matrix of hybrid type 2 showed a high degree of wear resistance. From these observations, it is apparent that the dispersion of colloidal silica among larger particles was effective in enhancing the wear resistance of the resin matrix itself. The submicronfiller also contributes significantly to compressive strength, elastic modulus and water absorption ${ }^{10,11)}$. Hybrid composite resins, such as type 2, may be desirable in stress-bearing posterior restorations. After two months, experimental composite resins showed characteristic wear patterns. There has been sufficient time to evaluate the final properties of composite materials after two months in vivo observation in this study.

\section{CONCLUSION}

1) Wear-damage was greater in the OCA than in the CFA in both types of hybrid composites.

2) Hybrid type 1, which contained organic fillers showed bulk fracturing in the OCA. By contrast, the facet surface of hybrid type 2, which contained colloidal silica, had a smooth appearance.

3) In the CFA, hybrid type 1 showed the preferred abrasion of the matrix resin and dislocation of quartz filler particles. Hybrid type 2 showed good wear resistance up to two months, due to reinforcement of the resin matrix by the dispersion of microfiller.

4) It was shown that the filler system contributed significantly to the wear resistance of composite resins. 


\section{ACKNOWLEDGMENT}

We gratefully acknowledge the expert technical assistance of Kuraray Co. Ltd., who made the experimental composite resins.

\section{REFERENCES}

1) Okamoto, A., Sekiya K., Fukushima M. Kota, K. and Iwaku M.: Direct observation for in vivo wear of composite resins, Dent Mater J 12: 54-61, 1993.

2) Lutz, F. and Phillips, R. W.: A classification and evaluation of composite resin, $J$ Prosthet Dent 50 : 480-488. 1983.

3) Craig, R. G.: Posterior composite resin dental restorative materials, $3 M$ Co., St. Paul, 1986, pp. 199211.

4) Lutz, F., Phillips, R. W., Roulet, J. F. and Setcos, J. C. : In vivo and in vitro wear of potential posterior composites, J Dent Res 63: 914-920, 1984.

5) Hosoda, H., Yamada, T., Inokoshi, S., Sano, H., Suzuki, Y. and Takatsuka, T.: Classification and elemental composition of fillers of composite resin, part 1 , classification of chemically cured composite resins, Japan J Conserv Dent 30 : 409-426, 1987. (in Japanese)

6) Hosoda, H., Yamada, T., Otsuki, M., Hosokawa, A. and Takatsuka, T.: Classification and elemental composition of fillers of composite resin, part 2, classification of light cured anterior and A/P composite resins, Japan J Conserv Dent $30: 427-442$, 1987. (in Japanese)

7) Hosoda, H., Yamada, T., Otsuki, M., Tatsumi, T. Sato, M., Inai, N. and Takatsuka, T.: Classification and elemental composition of fillers of composite resin, part 3, classification of light cured posterior composite resins, Japan J Conserv Dent 30 : 443-456, 1987. (in Japanese)

8) Hosoda, H., Yamada, T. and Kimoto, T.: Classification and elemental composition of fillers of composite resin, part 4, classification of facing and other composites, Japan J Conserv Dent 31 : 760 $-774,1988$. (in Japanese)

9) Phillips, R. W.: Skiiner's science of dental materials, 9th ed., W. B.. Saunders Co., Philadelphia, 1991, pp. 221-233.

10) Sub, B. I., Ferber, C. and Baez, R. : Optimization on hybrid composite properties, J. Esthetic Dent. 2 : 44-48, 1990.

11) Okamoto, A., Niwano, K., Sekiya, K., Linlin H., Fukushima, M. and Iwaku, M. : Effect of filler and matrix composition on the mechanical properties of experimental light-cured composite resins, Japan J Conserv Dent 36 : 1008-1019, 1993. (in Japanese)

12) Roulet, J. F.: Degradation of dental polymers, Basel : Karger, 1987, pp. 161-214. 


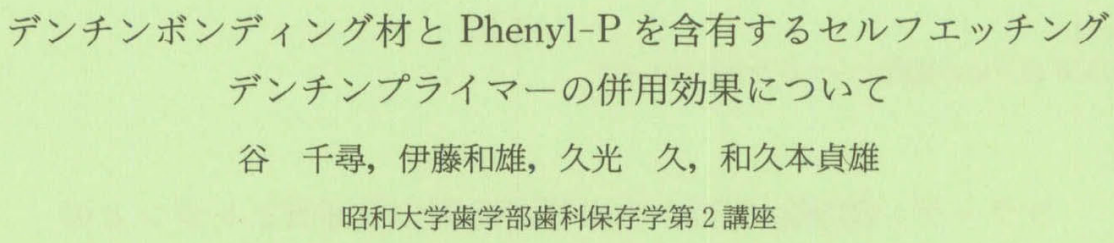

20 \% Phenyl-P を含む $35 \%$ HEMA 水溶液または, $35 \% \mathrm{GM}$ 水溶液からなるセルフエッチングデンチンプ ライマーを試作し，これらを 3 種類の市販ボンディング 材または，1種類の介在レジンと組み合わせた場合の接 着性能を，ヒト抜去歯に形成された象牙質円柱窩洞内で の市販可視光線重合型コンポジットレジンのコントラク ションギャップの計測により評価した. その結果, 今回 用いた材料の組み合わせでは, 試作プライマーで前処理 した窩洞に MDP を含む市販 Dual cure 型ボンディング 材を併用してコンポジットレジンを填塞した場合にのみ
完全な象牙質窩壁適合性が観察された。また，機能性モ ノマーを含まない介在レジンを併用した場合にも， Phenyl-P を含有するプライマーの前処理により, コン トラクションギャップの幅は有意に減少した.すなわち, Pheny-P を含有する HEMA または GM 水溶液をプラ イマーとして用いる場合には，それに続くデンチンボン ディング材を選択する必要があり,さらにプライマー中 に含まれる Phenyl-P は, 単にスメアー層処理のみなら ず，接着性の改善にも有効である可能性が示唆された。

\section{試作光重合型ハイブリッドコンポジットレジンのロ腔内磨耗像}

岡本 明, 関矢一仁, 福島正義, 岩久正明 新潟大学歯学部歯科保存学第一教室

本研究の目的は, in vivoにおける試験により, ハイプ リッド型コンポジットレジンの耐磨耗性に及ぽすイク ロフィラーの影響を評価することである. 2 種類のフィ ラーシステムを用いた試作光重合型レジン, すなわち, 有機複合フィラーを添加した八イブリッドタイプ 1 と, コロイダルシリカを添加したハイブリッドタイプ 2, が 試作された。 なお，試作レジンには, Bis-GMA (50 wt \%)と TEGDMA (50wt \%) からなるレジンモ)マーが 用いられた. $\mathrm{Au}-\mathrm{Pd}$ 合金製クラウンの咬合接触部
(OCA) と非接触部 (CFA) に設けた直径 $2 \mathrm{~mm}$ の円筒 形浻洞に試作レジンを充填し，ボランティアのロ腔内に クラウンを仮着した. クラウンは 1 月毎に撤去され, SEM による連続的観祭が行われた. 有機複合フィラー を添加したハイブリッドタイプ 1 は OCA において破壞 像を示した。一方, ハイプリッドタイプ 2 は, 高い耐磨 耗性を示し，これはマイクロフィラーによりレジンマト リックスが強化されたためと思われる.

\section{電気抵抗測定による合金の相変熊点決定上の測定電流の影響}

久恒邦博, 田中康弘, 有働公一, A. El-Araby, 岩沼健児 安田克廣

長崎大学歯学部㐘科理工学講座

合金の相変熊点 $\left(T_{\mathrm{C}}\right)$ を決定するための有効手段の 1 つである電気抵抗測定上における測定電流の影響を検討 した. 試料としては相変態に伴う電気抵抗変化の大きい
等原子比合金 $\mathrm{CuAu}$ を用いた. 温度計測は熱電対を試料 にスポット溶接した場合と, 通常のように試料近傍で両 者を接触させない場合の 2 方法で行なった. 後者の場合, 